\title{
THE PRINCIPAL'S ROLE IN THE FINNISH SCHOOLS
}

\author{
Nikola Radivojevic, $M S c$ \\ Economic High School \\ Kragujevac/Serbia \\ e-mail: $\underline{\text { ratkokg@gmail.com }}$
}

\begin{abstract}
A b s tract
A change of the school principal's role was marked as one of the most important catalysts in reforming Finnish educational system, the world leader in terms of learning results and students' achievements. Two factors have influenced the change of principal's role in schools in Finland: 1) rapid economic growth generated by technological innovation; and 2) the process of municipalization.
\end{abstract}

Keywords: principal's role, prosperity, process of municipalization.

\section{Introduction}

Finland is among the very few countries, that have been successful in developing and maintaining the value system, that connects contemporary innovation with creativity within strong and traditional social state, which supports high economic competitiveness, structurally and culturally. In that way, Finland has succeeded in reconciling, adjusting and integrating the elements that are separated in other developed economies and societies - prosperity, knowledge economy and social welfare. In other words, Finland has been successful in making a balance between changes on one hand and stability on the other. It was done in a manner connecting the whole country, and making the sense of belonging, where everyone is motivated to fight for the future of the nation.

Educational system was marked as the key element of the Finnish society's improvement and development. In order to play its social role efficiently, the educational system's transformation was necessary. The essence of reforming Finnish educational system is in creating national awareness about the meaning and the role of school in accomplishing social mission. A climate was created with the teaching profession as an attractive and desirable profession. Instruction quality has been provided, by creating appropriate conditions for attracting high level experts, through good working conditions, clear goal, status of autonomy and reward.

By engaging professional managers for the position of school principal (applicants for principal position, whether they are from teaching or non-teaching staff, 
which is not unusual situation in Finland, have to go through a special training in directing, administrating and familiarity with administration $)^{1}$, the quality of directing is provided. In contrast to principal's role in our schools, however, principal's role in Finnish schools are influenced by two factors, decisively: 1) rapid economic growth, generated by technological innovation; and 2) the process of municipalization.

\section{Principal's role in creating school as a "learning organization",}

In the past half-century, Finland went through significant economic and educational transformations. From undeveloped rural economy, with banking system totally collapsed in the late 1980s, and with unemployment rate of $18 \%$, Finland has become one of the leading European economies with the highest economic growth rate, in the late of the twentieth century (Hargeaves, 2007, p. 2). The heart of the Finnish "unbelievable metamorphosis" consists of rapid growth of technological innovation and clearly defined national goals, mandatory for everyone.

Maintenance of achieved economic progress rate and social welfare, has meant school transformation, i.e, redefining of principal's roles. Finnish society expects school (educational system) to support competitiveness of Finnish society (Damjanovic, 2010). Technological innovations growth generates a need for permanent competences development in the society.. Therefore, for school to fulfill expectations of the society, school transformation into "learning organization" is necessary. It is a process of creating sustainable change of behavior within school, inspired by desire to advance pedagogical processes, instruction, and school operation in general, based on reconceptualization of its relationships with an environment. The key role in the process, is played by principal. New principal's role is reflected in initiating of, and leading the transformation process. Namely, he or she is expected to define a desirable state, to define what school should look like, in order to efficiently meet the expectations of Finnish society, i.e, of local community, regarding its needs for future competences. In other words, the principal is expected to initiate the transformation process, to articulate a clear mental map and road to be followed. Efficiency and success of that process depend on a number of factors, but primarily on working collective, i.e, its mental map and willingness for maximal engagement in the process of realization. Therefore, the school principal is expected not only to create a vision (to define what school should look like) based on anticipated future (local community's need for future competences), but to convince his or her adherents (teachers) in its validity and correctness. ${ }^{2}$ It's about the process of gathering "strenght for transformation" (Radivojevic, 2006). Basically, it is a political process. There is an imperative for making a powerful coalition which will accept the need for "a new

\footnotetext{
${ }^{1}$ See: Teaching Qualifications Act, available at http://www.minedu.fi

${ }^{2}$ In the process of transformation, the Finnish schools principal's role is fully expressed at two facets: a) principal-teachers relationships (i.e, in comunicating the vision, motivating, resistance cushioning, etc.) and b) in the field of determining school course and elements of business policy (administering the transformation process - entrepreneurial initiative).
} 
organization". It is needed to select key agents that will actively support the process of transforming school into learning organization, because this is the process that represents a road to the unknown, moving from known and established patterns of behavior, toward new ones, not experienced by the collective, so far. That is exactly why they fear. Even when the need for necessity of transformation process is observed, if it is interpreted through existing (prevailing) system of values, beliefs and norms of conduct, only incremental changes will be made.

Consequently, there is a danger of school becoming divided into belligerent sides. Although the Finnish educational system is based on the view that highly professional ${ }^{3}$ teaching personnel works in schools, always should be kept in mind the fact that not everyone has an ability to understand the importance of anticipating future requests of local community, i.e, the need for school transformation. Besides, there is a danger that some teachers will recognize and accept the necessity of transforming school into learning organization, but will promote a different way of its realization. Therefore, a principal is expected to be efficient, not only in communicating the vision, but in resistance cushioning. In cushioning the resistance of teachers, the starting point is a view that resistance is unavoidable, and it's wrong to deny its existence. The strategy of closing eyes and running away from problems, is not the one that will contribute to their solution. The strategy of resistance cushioning is based on an observation that resistance does not come just from those who feel endangered directly. The lack of understanding this point, is causing one of the most frequent mistakes, made by executives in Serbia. They expect resistance to come only from those who are directly threatened by changes, and who feel the fear of losing something (a position, a job, power, etc.). It is true that a fear of personal loss is the most significant and most frequent cause of the resistance, but we must not neglect the fact that a human soul and the motivation mechanisms, are very complex and are influenced by a number of factors.

The process of transforming school into learning organization will come to its end when intellectual processes and feedback mechanisms at learning organization become built into employee's attitudes, norms od conduct and value system. That's how the school becomes so-called learning community (Hargeaves, 2007, p. 7). Learning community encourages and inspires a mutual cooperation, in efforts to promote pedagogical processes and learning outcomes, by analysing an existing practice and by exchange of knowledge and experiences.

Schools that act as strong learning communities are not just more successful concerning students achievements, but they deal with continuous changes, more efficiently (Fullan, 2003). In this kind of schools, the principal's role is to create strong and positive culture that motivates and mobilizes theachers to do their best in realizing the school purpose. However, in the case of Finland, this should be observed in a broader socio-cultural context. Namely, Finnish society encourages a growing devotion to performance improvement, by creating common vision, common needs and beliefs,

\footnotetext{
${ }^{3}$ This is a key reason why organization of educational system in Finland has not provided for institutions dealing with an inspectoral monitoring.

93
} 
expressed as common practice and way of living. In the heart of the Finnish educational system is the culture of mutual trust, cooperation ande responsibility. In Finland highly qualified teachers have a strong sense of duty regarding all students and students' wellbeing. This kind of responsibility is not just a Lutheran feature, coming from a high appreciation for hard work and conscientiousness, but is a consequence of taking care of an individuals' well-being, as well as that of the community, within a broader vision of Finnish society.

\section{Principal's role and the process of municipalization}

An important element of Finnish society's metamorphosis is the process of decentralization, i.e, municipalization, as called in Finland. It's a very complex process of transfering responsibility and authority from the governmental (state) level to the local level. On the one hand, the municipalization process has brought the increased school autonomy, but on the other hand, there is now an increased responsibility for better using of knowledge base, pedagogical processes, as well as an increased responsibility for contribution and support for local communities, other schools and public services. If a school and local community are provided for resources, the principle is to find a better solution (Rajala, 2006). Principals have a full discretion in making decisions, but also a responsibility for school organization, budget distribution, interpretation and implementation of legislation, making and realizing plans of action, staffing and forming teams, delegating the authority (development of the participative leadership), resource management, relationships with parents, etc. On the other hand, municipalization process has caused principals to actively participate in local community's goals definition, and in establishing an active cooperation with other schools, in order to use resources more efficiently and to achieve local community's goals, effectively. The emphasis is on the principle who everyone in the local community has to work with for the sake of all students in the municipality (Tornberg, 2009).

This cooperation is based on mutual trust, and is characteristic not only of Finland, but of other Scandinavian countries, too. In this respect, a school principal is responsible not only for success of his or her own school, but also for the operation of other schools in the local community. Thus, in Finland it is not unusual to find principal who is in charge of three schools. This practice makes possible easier coordination and school's partial goals control, transfer of positive practice and experiences, more efficient resources allocation and usage. Also, there is an effect of budgetary saving, since schools are owned by the local governement-owned. Namely, if a person serves as principal in three schools, he or she receives only one salary. Because the school principals are responsible for success and quality of schools functioning in the local community anyway, this does not make any difference regarding responsibility.

However, in administrative model of this type, there is always a potential danger of principal's duties (tasks) quantity to be larger than a person can handle. In that case, the process of transforming school into learning organization will be inefficient, 
eventually leading to poor work quality, and beyond, to unrealized but defined goals of local community.

A crucial issue for success of principals' joint working efforts, is creating a mutual trust. In that way, an institution of "collective responsibility" is developed. The principals' willingness is based on a belief that it's necessary to incorporate more people, similar to them, into "system" (principal's team, the institution of collective responsibility), in order to advance and improve educational system, and further, local community's life quality. The institution of collective responsibility, by no means represents a substitute for individual responsibility the principal has. On the contrary, the institution of collective responsibility represents an additional (external) mechanism of principal's work control. If the principal is ineffective, other schools principals in the community, point out his or her mistakes and give him or her all the help and support he or she needs. This is how the instituion of collective responsibility represents a mechanism of a principal's work control. Because their cooperation is based on mutual trust, nobody questions their professionalism and expertise, as well as an intention of any principal included in the control.

\section{Instead of conclusion}

The school transformation process, must be seen within the context of general social transformation, the essence of which lies in the fact that it is driven by clear goals, mandatory for everyone. The key role at school transformation, belongs to the principal. The effect of municipalization and Finnish society's expectations regarding school's role (educational system) have led to situation at which principals must be efficient leaders for their adherents, in the process of creating school as a learning organization, and further, transforming it in a learning community. Therefore, the principal's role is extended to a role of initiator and a bellwether at transformation processes.

Besides, municipalization process caused principals to get a new additional role the role of participants in defining and realizing the local community's goals, and to provide help in assuming a responsibility for achievements of all schools in the local community.

\section{References}

1. Damjanovic, Radojko (2010), Finski obrazovni sistem - refleksija jedne studijske posete (not finished).

2. Hargeaves, Andrew et al. (2007), School leadership for systematic improvement in Finland, A case study report for OECD activity: Improving school leadership.

3. Fullan, Michael (2003), Change Forces with a Vengeance, Routledge, London. 
4. Ministry of Education, Department for Education and Science Policy, (2007), Improving School Leadership, Country Background Report for the OECD Activity Improving School Leadership, Helsinki

5. Rajala, Raimo et al. (2000), The Role of School Leadership in Learning at Work and Professional Development in Three European Countries, Research, University of Lapland, Finland

6. Radivojevic, Nikola (2006), Uloga lidera u procesu poslovne transformacije preduzeća, Symposium: Leadership in theory and practice, Banja Luka 15/01/2010)

7. Teaching Qualifications Act, available at: http://www.minedu.fi (date of updating:

8. Tornberg, Aki (2009), The Finnish education and decision making sistem, Presentation, Ministry of Education, Finland

Metodički obzori 9; vol. 5(2010)1

Stručni rad

UDK: 371.111

Primljeno: 27. 4. 2010

\section{ULOGA DIREKTORA U FINSKIM ŠKOLAMA}

Mr. sc. Nikola Radivojević Ekonomska škola, Kragujevac, Srbija e-mail: ratkokg@gmail.com

Re zime

Promena uloge direktora škole označena je kao jedna od najznačajnijih katalizatora refomre finskog obrazovnog sistema, koji je svetski lider kada su u pitanju rezultati učenja i postignuća učenika. Dva činioca su uticala na promenu uloga direktora u finskim školama: 1) rapidan ekonomski rast generisan tehnološkim inovacijama i 2) proces municipalizacije tj. opštinizacije.

Ključne reči: uloga direktora, prosperitet, municipalizacija 